\title{
LAND PROTECTION AND LAND CARE IN SLOVAK REPUBLIC
}

\author{
Martin Dufala, Lenka Dufalová, Jana Šmelková \\ Comenius University in Bratislava, Faculty of Law
}

\begin{abstract}
The land as a part of the environment is in a special position. It is a part of the environment and also it is a productive resource. This determines the legislation relating to the land. The article deals with the current legislation regarding land as well as with the issue of the constitutional protection of land, for example the rules of acquisition of agricultural land in constitution.
\end{abstract}

Key words: land, environment, ownership, transfer, protection

\section{INTRODUCTION}

Paper analyses legal regulation of land protection which has specific position as it is one of the components of the environment and natural resource, but at the same time it has economic and productive potential; it is subject to ownership of natural persons and legal entities and serves as a place for realization of many human activities.

This special position also significantly affects legislation regulating land care and ownership of land. Therefore we can conclude that the land regulation is inconsistent and regulates the social relations in two levels:

a) protection of land as a component of the environment,

b) regulation of ownership and other relations to the land.

Transfer of ownership to the land is covered by special legal regime in the form of constitutional protection and specific statutory restrictions. Topic of the paper is actual due to the amendment to the Act no. 460/1992 Coll. Constitution of the Slovak Republic (hereinafter "Constitution") by which special protection of agricultural land, forest land and food security of the state was established by the Constitution.

It is very demanding to deal with legislation regulating all aspects of the protection, use and ownership of the land. Within the scope of this paper it is impossible to cover all the legislation, therefore we have focused on the selected ecological and economic aspects of land protection and land ownership governed in particular by the following legislation:

- Act no. 460/1992 Coll. Constitution of the Slovak Republic, as amended,

- Act no. 220/2004 Coll. on the protection and use of agricultural land and amending Act no. 245/2003 Coll. on integrated pollution prevention and control and amending certain laws, as amended,

- Act no. 140/2014 Coll. on acquisition of ownership of agricultural land, as amended,

- Act no. 202/1995 Coll. The foreign exchange act and the act amending and supplementing Act of the Slovak National Council no. 372/1990 Coll. on infringements, as amended,

- Act no. 543/2002 Coll. on Nature and Landscape Protection, as amended, 
- Act no. 326/2005 Coll. on Forests, as amended,

- Act no. 364/2004 Coll. on Water, as amended,

- Act no. 79/2915 Coll. on Waste, as amended,

- Act no. 39/2013 Coll. Act on Integrated Pollution Prevention and Control, as amended.

\section{LAND AS A COMPONENT OF THE ENVIRONMENT AND ITS PROTECTION}

Until May 31 $1^{\text {st }}, 2017$ protection of land in the Constitution was regulated by the general protection of the environment, in particular by means of Article 4 and Article 44 . Article 4 refers to the exclusive ownership of some components of the environment, resp. of natural resources, and stipulates special water protection. Article 44 also regulates right to favourable environment, a general duty to protect and enhance the environment, as well as the role of the state in ensuring environmentally friendly use of natural resources, ecological balance, effective environmental care and protection of selected plant and animal species. With effect from June $1^{\text {st }}, 2017$ special protection of land has been stated in the Constitution, not only as a component of the environment but also with some particularities in relation to the acquisition of its ownership. Chapter 3 of the paper analyses constitutional land protection.

Further legislation on the land protection as a component of the environment is based on Article 44 para. 6 of the Constitution, according to which further details on the rights and obligations stated in Article 44 of the Constitution are governed by a special legal acts.

Land as a component of environment is part of a specific territory of different categories and different types which are protected by a relatively wide legislation. This may be regarded as the first lack of legal regulation, i.e. inconsistency and large amount of land protection legislation as a component of the environment. Legislation regarding land protection and land care can be divided into two groups:

1. legal acts regulating different categories of territory with the land as a part of these territories mainly Act on Nature and Landscape Protection, Act on Water, Act on Forests and Act on the protection and use of agricultural land,

2. legal acts regulating land protection against sources of danger or damage - mainly Act on integrated pollution prevention and control, Act on Waste, Act no. 44/1988 Coll. on the protection and utilization of mineral resources (The Mining Act), Act no. 188/2003 Coll. on Application of Sludge and Bottom Sediments into the Land and on amendment of Act no. 223/2001 Coll. on Waste and Act No 136/2000 Coll. on fertilizers.

\section{Act on Nature and Landscape Protection}

The legislation on nature and landscape protection contributes to land protection mainly by territorial protection, which is part of the special nature and landscape protection. Special protection is more stringent than general protection of nature and landscape as it represents a sum of over-standard rules that apply in relation to exceptional and unrepeatable components of the environment. ${ }^{1}$

1 CEPEK., B. et al. Environmentálne právo. V̌̌eobecná a osobitná čast', p. 261. 
Territorial protection means the protection of nature and landscape in the territory of the Slovak Republic or its part. The territorial protection specifies five levels of protection. ${ }^{2}$ The Act states prohibition of activities for individual levels of protection and the scope of restrictions and prohibitions increases with an increasing level of protection. Under the Act, certain types of activities may be carried out only with the approval of the competent nature protection authority.

The Nature and Landscape Protection Act contributes to the protection of the territory by designation of protected areas and their protective zones, including, for example, national parks, protected landscape areas, nature reserves, protected bird areas and others ${ }^{3}$. The relationship between levels of protection and protected areas is important for the protection of the territory. First level of protection applies in the territory of the Slovak Republic, unless the Act on Nature and Landscape Protection provides otherwise. The first level of protection is governed by the general nature and landscape protection provisions included in the part two of the Act. At the same time, the Act determines what level of protection is intended for a particular type of protected area, e.g. in the territory of the nature reserve and the national nature reserve the fourth or fifth degree of protection applies.

The Nature and Landscape Protection Act by designation of different types of protected areas, their protective zones and levels of protection, in which the influence of humans on a given territory is regulated by the prohibition or restriction of certain activities, also contributes to the protection of the land located in these protected areas.

\section{Act on Water}

The primary role of the Water Act is the multiple protection of surface water and groundwater, including ecosystems. However, these waters do not exist independently of the territory, resp. of the land substrate from which they are pumped. This is also obvious from the definition of groundwater, which is characterized as all water which is below the surface of the ground in the saturation zone and in direct contact with the land or subsoil ${ }^{4}$. Therefore, the protection of water is ensured by the protection of certain parts of the territories, the protection of which significantly contributes to the quality and safety of the water and, at the same time, to the protection of the land in that territory.

Within the protection of water regulations and water resources stated in the fifth part of the Water Act, protected water areas, protective zones of water resources, sensitive zones and vulnerable zones are declared. Furthermore, the protection of water from nitrate pollution from agricultural sources and the rules for waste water discharge into surface waters and groundwater are regulated in this part of the Act.

Territory, which, by its natural conditions, constitutes a significant natural accumulation of water, may government designate as a protected water $\operatorname{area}^{5}$. In the protected water area it is only possible to plan and carry out any activity if the protection of surface water and groundwater is guaranteed. The Water Act also enumerates activities which are prohibited to carry out in the protected water area.

\footnotetext{
$\$ 11$ of the Act on Nature and Landscape Protection.

$\$ 17$ and following of the Act on Nature and Landscape Protection.

$\$ 3$ para. 3 of Water Act.

$\S 31$ of Water Act.
} 
Pursuant to the Water Act, water resources are defined as water in the bodies of surface water and in the bodies of groundwater used for water abstraction for drinking-water or available for water supplement of population of more than 50 persons, or allowing for the water abstraction for such a purpose in the amount more than $10 \mathrm{~m}^{3}$ a day as an average in their original condition or after their regulation. In order to protect capacity, quality and health of the water resources used, state water administration authority will determine the protective zones on the basis of the opinion of the health protection authority. The protective zones of water resources are divided into:

(a) protective zone of the $1^{\text {st }}$ level - it serves to protect water resource in the immediate vicinity of the water abstraction point or the capture facility,

(b) protective zone of the $2^{\text {nd }}$ level - it serves to protect the water resource from being at risk from distant locations,

c) protective zone of the $3^{\text {rd }}$ level - the authority of the state water administration may determine it in exceptional cases to increase the protection of the water supply.

Limits and method of protection, in particular prohibitions or restrictions of activities that harm or threaten the quantity and quality of water or the health of the water in the water resource, shall be determined in the decision on the designation of protective zones of the water resource.

Criteria for sensitive areas identification and waters in vulnerable areas are set out in Annex no. 3 and Annex no. 4 of the Water Act.

The water protection legislation illustrates how the protection of the various components of the environment is relevant, in this case water and land. Quality or possible pollution and damage to water can significantly affect condition of land and vice versa.

\section{Act on Forests}

Within the environment, forest is an important and complex ecosystem formed by a forest land plot with a forest vegetation and factors of its air environment, plant species, animal species and land with its hydrological and air regime. The Forest Act defines, inter alia, forest land plots and their protection, and its purpose is to preserve, enhance and protect forests as a component of the environment and the country's natural resources to fulfil their irreplaceable functions.

The protection of forest land plots is primarily provided by the fact that forest land plots can be primarily used to fulfil functions of forests (whether productive or non-productive). For other purposes, they may only be used on the basis of a decision of the competent state administration forestry authority that may decides about its temporary or permanent exemption from the functions of forests or about restrictions on the use of forest functions on them. Where appropriate, the prior opinion of the competent state administration authorities is required. The exemption or limitation of use can only take place in inevitable and justified cases. The legal entity or natural person who applied to exempt the forest land plot is obliged to compensate for the loss of non-productive functions of the forest, "levy".

The protection of forests and forest lands is also ensured by the designation of so called protective forests and special purpose forests where the management is limited. The Forest Act establishes an obligation for the forest owner to protect the forest, especially in the form of preventive measures in order to prevent forest damage and protective and defensive measures against damages caused by harmful facts. 
Forests form a large part of the territory of the Slovak Republic, therefore the protection of forests and forest land plots contributes significantly to the protection of the land, which falls under the legal regime of forest land.

\section{Act on the Protection and Use of Agricultural Land}

The subject of this Act is agricultural land, which is characterized as a productively potential land registered in real estate cadastre as arable land, hop fields, vineyards, fruit orchards, gardens and permanent grasslands. The Act provides for the protection of the characteristics and functions of agricultural land, ensuring its sustainable management and agricultural use, protection of its environmental functions, as well as the protection of its areas from unauthorized use for non-agricultural purposes.

Regarding protection of agricultural land, the Act sets out principles of sustainable use and management. It is the responsibility of the owner to ensure proper management of agricultural land, i.e. implementation of agro-technical measures for protection and preservation of qualitative features and functions. If the land plots are not cultivated, the land owner it is required to prevent the occurrence of weeds. ${ }^{6}$ Furthermore, the owner is obliged to take measures to protect the land against negative phenomena, which are in particular degradation, erosion, compaction and protection of agricultural land against harmful substances.

Since agricultural land area extent is limited and by the use for other purposes it is diminishing, the Act on the Protection and Use of Agricultural Land regulates the principles of the protection of agricultural land for non-agricultural use. Also, as in the case of forest land exemptions, it is true that agricultural land can be used for construction purposes and other non-agricultural purposes only in inevitable cases and to a reasonable extent. Exemption for non-agricultural purposes is possible only on the basis of an exemption decision. The decision is issued by the authority responsible for the protection of agricultural land in which responsibility the agricultural land proposed for removal is situated. Removal may be permanent or temporary (up to 10 years). In the decision, the authority for the protection of agricultural land shall determine the conditions for exemption, such as the recultivation of the temporarily exempted agricultural land or the payment of the levy for permanent withdrawal or temporary withdrawal of the highest quality agricultural land.

Agricultural land, in addition to its protection, enjoys some specific protection also in relation to the acquisition of its property, which is discussed in the second chapter of the paper.

\section{Act on Integrated Pollution Prevention and Control}

Integrated pollution prevention and control is a set of measures to prevent environmental pollution, reduce emissions into air, water and land, reduce waste generation, and to recover and dispose of waste in order to achieve a high overall level of environmental protection ${ }^{7}$. Integrated authorisation is then a procedure that allows, in a coordinated manner, the conditions for the implementation of activities in existing facilities and in new facilities in order to guarantee the effective integrated protection of environmental components. Thus, when authorising certain industrial activities, the protection of several components of the environment, including land, is addressed in one procedure.

KOŠIČIAROVÁ, S. et al. Právo životného prostredia, p. 429.

$\S 2$ (a) of Act on Integrated Pollution Prevention and Control. 
Integrated authorization results in integrated permission. It is a decision which entitles the operator to carry out an activity in the operation or its part and which determines the conditions for carrying out activities in the operation. This decision also provides for conditions to ensure the protection of land against pollution or damage from such industrial activities.

The requirements for the periodic monitoring of the land in relation to dangerous substances which may be found at the place of operation are also set out in the conditions for the operation of these activities. At the same time, the competent authority shall determine the measures to be taken after termination of activities. This may be, for example, revitalization of the land.

\section{Act on Waste}

Within the framework of the waste management legislation, the legislation on landfilling and on responsibility for illegal waste placement is relevant in relation to land.

Landfill is a site with a waste disposal installation where waste is permanently deposited onto or into land ${ }^{8}$. The Act establishes obligations of landfill operators, in particular close, reclaim, monitor and to eliminate the adverse situations and impacts that they become aware of while monitoring the landfill.

Considerable damage to the environment, and therefore to the land, may be caused by waste that is located elsewhere than it is designated for. $\$ 15$ of the Waste Act deals with the procedure for identifying person responsible for illegal waste placement and the process of recovering or disposing of such waste in order to prevent the leak of various substances into the land, water and other components of the environment.

\section{LAND AS SUBJECT TO OWNERSHIP AND ITS PROTECTION}

The basic legal Act directly related to the possibility of agricultural land acquisition is Act no. 140/2014 Coll. on acquisition of ownership of agricultural land. This Act regulates the transfer of agricultural land and the competence of specific bodies operating in this area.

Agricultural land plot is legally defined as an agricultural land or land built up with a construction for agricultural purposes until June 24, 1991. ${ }^{9}$ However, this does not include specific types of agricultural land such as:

a) gardens regardless of their location;

b) a land plot in a municipality's built-up area regardless of its type;

c) a land plot outside the municipality's built-up area if:

- it is intended for other than agricultural use;

- the possibility of its agricultural use is limited by separate regulations;

- its acreage is less than $2,000 \mathrm{~m}^{2}$;

d) it is adjacent to the construction, together with which it creates one functional whole.

$\$ 5$ para. 5 of Act on Waste.

$\$ 1,2$ of Act no. 140/2014 Coll. on acquisition of ownership of agricultural land. 
Regarding the acquisition of ownership, agricultural land as a subject to legal protection is subject to a special regime. For the purposes of the herein before mentioned law, transfer of ownership may be done by:

- a conditional conveyance

- a voluntary conveyance

- transfer for the purposes of the enforcement of lien

- transfer for the purposes of the enforcement of the security transfer of right.

In each case of transfer, legislator refers to the Civil Code and its specific provision. Therefor it can be assumed that agricultural land cannot be the subject of a transfer under other legislation, e.g. under the Commercial Code, where the transfer of real estate would otherwise be considered as a contract for the purchase of the leased item or a contract on sale of an enterprise. ${ }^{10}$

However, restrictions regarding the use of specific types of contract shall not apply in cases of exchange of agricultural land under the Civil Code (barter contract), as this acquisition of ownership is not governed by this legal act. Exchange of land plot pursuant to Section 611 of the Civil Code represents separate option for the transfer of ownership, provided that exchanged land plots are comparable - the difference in their value is not more than $10 \%$. Furthermore, the Act and conditions for the acquisition of ownership do not apply to:

- voluntary conveyance of the ownership under the Act no. 229/1991 Coll. on Regulation of Ownership Relations to Land and Other Agricultural Property, as amended and under the Act no. 503/2003 Coll. on Restitution of Ownership of Land and on the Change and Amendment to Slovak National Council Act no. 180/1995 Coll. On Certain Measures for Land Ownership Arrangements, as amended,

- special cases of ownership transfer such as: land exchange, purchase of land and the pre-emption of the state under the Act no. 543/2002 Coll. on Nature and Landscape Protection, as amended, sale of land by the Slovak Property Fund under Regulation of the Government of the Slovak Republic no. 238/2010 Coll. stipulating Details on Terms of Rent, Sale, Exchange and Acquirement of Immovable Property by the Slovak Property Fund,

- land consolidations under Act no. 330/1991 Coll. on Land Consolidation, Arrangement of Land Ownership, Land Registries, the Land Fund, and Land Parcel Associations, as amended,

- transfer of ownership by expropriation in public interest e.g. under the Act no. 50/1976 Coll. on land-use planning and building order (the Building Act) as amended or under the Act no. 129/1996 Coll. on some measures to accelerate the preparation of highways and roads construction for motor vehicles, as amended.

The procedure of ownership transfer regarding these forms of transfer the of agricultural land is very specific under the Act. The land owner is entitled to transfer the land plot to a person carrying out agricultural production as a business for at least three years in the municipality, where the agricultural land is located or to a co-owner of an agricultural land plot, a close person or a relative person under the Civil Code. In these cases, the transfer takes place without the need for a special procedure.

Special conditions regarding conditional and voluntary conveyance verified by the competent District Office are:

1. an offer to transfer the land plot shall be published in the Register of published offers on transfer of agricultural land the website of the Ministry of Agriculture and Rural Development of the SR and on the official board of the municipality at least for a period of 15 days,

10 Under $\$ 409$ of the Act no. 513/1991 Coll. Commercial Code, real estate cannot be transferred by the purchase contract. 
2. acquirer must meet following conditions: permanent residence or registered office in the territory of the Slovak Republic for at least 10 years and carrying out agricultural production as a business for at least three years,

3. preference is given as follows: at first place is applicant from the municipality where the agricultural land plot is registered, second place belongs to the acquirer from the municipality adjacent to the municipality in which the agricultural land plot is located and the third place belongs to the acquirer regardless of the place of business,

4. possibility to extend the offer of transfer to subjects fulfilling the aforementioned assumptions, regardless of the place of business, subsidiary - following a request for taking by persons from the adjacent municipality,

5. possibility to extend the offer of transfer to subjects who have permanent residence (or registered office) in the territory of the Slovak Republic for at least 10 years after the expiry of 6 months period with no effect,

6. obligation to record the interest in the acquisition of ownership of the offered land in the Register,

7. obligation to identify acquirer interested in land plot transfer who has preliminary agreed to enter into contract with the transferee in the register.

Agricultural production as a prerequisite for being an acquirer of the land is fulfilled when it is carried out as a business or as a dependent work. Even the obligation of at least three years of operation does not apply to young farmers ${ }^{11}$ who, however, may not rent, sell or donate the land for three years from acquiring the ownership of the agricultural land. ${ }^{12}$

Before the conclusion of the specific contract for the transfer of ownership, the acquirer has the obligation to ask competent District Office to issue a certificate on fulfilment of the requirements to be subject to land transfer. However, the acquirer may ask municipality to issue a confirmation provided that acquirer is not subject to special transfer. The Act states that even land plots that are not agricultural land plots under the legislation cannot be transferred without confirmation of a special character. If land plot is to be transferred after the expiry of stated period with no effect, it is the acquirer's obligation to provide confirmation of the permanent residence. ${ }^{13}$

Under the Act specific subjects may not acquire an agricultural land: state, state citizen, natural person with permanent residence or legal entity with registered office in the state whose legislation does not allow citizens of the Slovak Republic, natural persons with permanent residence in the Slovak Republic or legal entities with registered office in the Slovak Republic acquire ownership of the agricultural land plot; this does not apply to inheritance of agricultural land plot. Exception to the restriction are member states of the European Union, the European Economic Area, Switzerland and to the states, the international treaty of which provides so, and the Slovak Republic is bound by it as well. ${ }^{14}$

11 Young farmer is a person who is less than 40 at the moment of submitting the application, possesses adequate occupational skills and competence and is setting up for the first time in an agricultural holding as head of the holding - Article 2 par. 1 (n) of the Regulation of the European Parliament and of the Council (EU) no. 1305/2014 on support for rural development by the European Agricultural Fund for Rural Development (EAFRD) and repealing Council Regulation no. $1698 / 2005$.

$12 \$ 4$ of the Act No.140/2014 Coll. on acquisition of ownership of agricultural land.

$13 \$ 6$ of the Act No.140/2014 Coll. on acquisition of ownership of agricultural land.

$14 \$ 7$ of the Act No.140/2014 Coll. on acquisition of ownership of agricultural land. 


\section{CONSTITUTIONAL LAND PROTECTION}

After joining the European Union on May 1 1 ${ }^{\text {st }}, 2004$ Slovak Republic applied moratorium on sale of agricultural land to foreigners - natural persons for a period of seven years, valid until April $30^{\text {th }}$, 2011. However, in January 2011, the moratorium on the purchase of agricultural land by foreigners was extended by another three years, t. j. until April 30"h, 2014.

From June $1^{\text {st }}, 2014$, there is valid and effective Act no. 140/2014 Coll. on acquisition of ownership of agricultural land under which the owner or other person entitled to transfer ownership of an agricultural land may sell an agricultural land in the ownership of:

a) a person carrying out agricultural production in the municipality, where the agricultural land is located,

b) a person entitled to acquire ownership of an agricultural land and carrying out agricultural production as a business in the municipality adjacent to the municipality in which transferred agricultural land is located,

c) a person regardless of his permanent residence or registered office and regardless of whether he is natural or legal person.

Regarding the Act, a following question has arisen: from the point of view of the constitutional protection of property rights (in particular one of its components - ius diponendi with the subject of ownership), isn't it a disproportionate interference with ownership?

On May $26^{\text {th }}, 2016$, a request from the European Commission was addressed to the Slovak Republic to amend the national legislation on the possibility of acquiring land in the Slovak Republic by foreigners. The same request was presented in the other four EU Member States: Bulgaria, Lithuania, Latvia and Hungary. According to the European Commission changes in the land acquisition legislation was necessary because national legislation infringes the free movement of capital and the freedom of establishment.

As an answer, the Slovak Republic has provided a promise of changes in legislation and its alignment with the European Commission's request. But, for example, Hungary considered the European Commission's request as an interference in its internal affairs and refused to change the legislation. The European Commission's response has been a motion sent to The Court of Justice of the European Union on the restriction of the free movement of capital and hence on obstacles for cross-border investors in agriculture.

Ultimately, approach of the Slovak Republic was essentially the opposite to its previous statement. As a result, an amendment to the Constitution which introduced a special protection of the land was adopted. This amendment is based on the requirement to extend the obligation of the state to pay particular attention to the protection of agricultural land and forest land and the promotion of rural life. In addition, a new separate paragraph has been added to the Constitution, which establishes the definition of land (agricultural and forestry) and establishes the obligation of the state to preserve the land, including its productive status for future generations. The land is defined as a non-renewable natural resource, i.e. it cannot be confused with the term goods ${ }^{15}$.

The amendment to the Constitution regarded its three provisions. In Article 20 para. 2, which provides for certain restrictions on the ownership right, the restriction of the exercise of the right of

15 See General part of the Explanatory Statement to the Constitutional Act no. 137/2017 Coll., amending the Constitution of the Slovak Republic no. 460/1992 Coll. as amended. 
ownership has been amended also for food security. Article 44 para. 4 was amended by the obligation of the state to pay particular attention to the protection of agricultural land and forest land. Article 44 contains a new paragraph 5 , which defines agricultural land and forest land as non-renewable natural resources, which enjoy special protection of the state and society.

\section{CONCLUSION}

Based on the above, it can be stated that the legislation on land care and its protection is very extensive and inconsistent, which is justifiable by the existence of several legal regimes of land use as part of a certain territory. A specific area, which should also take into account the environmental aspects of land protection and use, is the regulation governing the acquisition of land ownership. Even in this case, it is important to know what kind of land it is.

Effective from June $1^{\text {st }}, 2017$ a significant change to the land legislation has been done. By an amendment to the Constitution a special land protection was introduced to Slovak legislation. Following the specific protection of water in Article 4 para. 2 of the Constitution we have special protection of other component of the environmental. However, this component has a specific status because it is also a productive factor and a subject of private ownership. This change results in some interference or restriction of ownership of agricultural land and forest land, which may raise questions about the compatibility of this legislation with EU law. Arguments put forward by the authors of new legislation are based on the exception to the prohibition of restrictions on the free movement of capital under Article 65 of the Treaty on the Functioning of the European Union ${ }^{16}$, according to which Member States may take restricting the free movement of capital if they are justified on grounds of public policy or public security. Therefore, it will be interesting and necessary to see how the European Commission, possibly other EU bodies, will react to the Slovak legislation.

\section{Bibliography:}

CEPEK., B. et al. Environmentálne právo. Všeobecná a osobitná čast. Plzeň : Vydavatelství a nakladatelství Aleš Čeněk, 2015. 442 p. ISBN 978-80-7380-560-9.

KOŠIČIAROVÁ, S. et al. Právo životného prostredia. $2^{\text {nd }}$ Edition. Žilina : Poradca podnikatela, 2009. 680 p. ISBN $978-$ 80-89363-13-1.

Zákon č. 460/1992 Zb. Ústava Slovenskej republiky

Zákon č. 220/2004 Z. z. o ochrane a využívaní polnohospodárskej pôdy a o zmene zákona č. 245/2003 Z. z. o integrovanej prevencii a kontrole znečistovania životného prostredia a o zmene a doplnení niektorých zákonov

Zákon č. 140/2014 Z. z. nadobúdaní vlastníctva polnohospodárskeho pozemku

Zákon č. 202/1995 Z. z. devízový zákon a zákon, ktorým sa mení a dopĺňa zákon Slovenskej národnej rady č. 372/1990 Zb. o priestupkoch v znení neskorších predpisov

Zákon č. 543/2002 Z. z. o ochrane prírody a krajiny

Zákon č. 326/2005 Z. z. o lesoch

Zákon č. 364/2004 Z. z. o vodách

16 Available at:

http://eur-lex.europa.eu/legal-content/SK/TXT/?uri=CELEX\%3A12012E\%2FTXT, cited on: 15. 11. 2017. 
Zákon č. 79/2015 Z. z. o odpadoch

Zákon č. 513/1991 Zb. obchodný zákonník

Nariadenie Európskeho parlamentu a Rady (EÚ) č. 1305/2013 zo 17. decembra 2013 o podpore rozvoja vidieka prostredníctvom Európskeho polnohospodárskeho fondu pre rozvoj vidieka (EPFRV) a o zrušení nariadenia Rady (ES) č. 1698/2005 (Ú. v. EÚ L 347, 20. 12. 2013) v platnom znení.)

Všeobecná čast’ Dôvodovej správy k ústavnému zákonu č. 137/2017 Z. z., ktorým sa mení a doplňa Ústava Slovenskej republiky č. 460/1992 Zb. v znení neskorších predpisov

Zmluva o fungovaní Európskej únie (Konsolidované znenie)

http://eur-lex.europa.eu/legal-content/SK/TXT/?uri=CELEX\%3A12012E\%2FTXT, cit. 15. 11. 2017.

\section{Contact information:}

Mgr. Martin Dufala, PhD.

martin.dufala@flaw.uniba.sk

Comenius University in Bratislava, Faculty of Law

Mgr. Lenka Dufalová, PhD.

lenka.dufalova@flaw.uniba.sk

Comenius University in Bratislava, Faculty of Law

Mgr. Jana Šmelková, PhD.

jana.smelkova@flaw.uniba.sk

Comenius University in Bratislava, Faculty of Law

Šafárikovo nám. č. 6

P. O. BOX 313

81000 Bratislava

Slovak Republic 